\title{
WINTERING RECORD OF BLACK GUILLEMOTS OFF NORTHERN MANITOBA
}

\author{
by ROBIN BEST*
}

Black Guillemots have been recorded in Manitoba approximately 10 times since they were first reported by Preble in $1900 . .^{123}$

With one exception, these records are for the summer and fall months, ranging from June 28 to October 10 , or roughly the ice-free season for the Churchill area, where these sightings have been made.

The only winter record for the province is a specimen that was found dead near Morris. Manitoba, on November 12,1966. A description of the specimen, and a review of the previous literature on the occurrence of this species in the province has been published in the Blue Jay. ${ }^{3}$

On February 21 and 22, 1974, 200300 guillemots were observed in the ice-pack approximately 45 to 80 miles offshore from the Churchill and Cape Churchill coastline during a Polar Bear survey by the Canadian Wildlife Service (H. P. L. Kiliaan and B. M. Knudsen, pers. comm.). The birds were seen in small flocks of 15 to 40 birds in the large leads in the pack-ice. An additional sighting of a single bird was made by the author on March 21, 1974, again, some 40 to 50 miles northeast of Churchill.

On March 8, 1974, a live adult Black Guillemot, in full winter plumage, was found near Mile 4 on the Churchill road by two Department of Public Works employees. This bird later died and was sent to the Manitoba Museum of Man and Nature.

Although the guillemot is known to winter off Southampton Island, James Bay, and "probably about the open leads along the east side of Hudson's Bay ..."4, there appear to be no records for western Hudson's Bay. It is possible that the Black Guillemot population that breeds and winters in the Southampton Island area moves south in very cold winters, such as 1973-74, when the ice conditions are poor.

These observations constitute the first evidence of Black Guillemots wintering in the waters off Manitoba. A record of the second specimen for the province of Manitoba is included.

I am grateful to David Hatch for his assistance in determining the status of this recent specimen, and in supplying additional information.

${ }^{1}$ COOKE, F.. A. J. PAKULAK, R. K. ROSS and R. K. SCHMIDT. 1973. Birds of the Churchill Tundra Biome. Manuscript. 34 p. Dept. of Biology, Queen`s University, Kingston, Ontario.

-JEHL. J. R. jr. and B. A. SMITH. 1970. Birds of the Churchill region. Manitoba. Manitoba Museum of Man and Nature Special Pub. 1.87 p.

3 NERO, R. W. 1968. Manitoba Black Guillemot specimen. Blue Jay 26: 14-15.

${ }^{4}$ SNYDER, L. L. 1957. Arctic birds of Canada. University of Toronto Press. 310 p. 